Int. J. Electrochem. Sci., 15 (2020) $2385-2398$

International Journal of

ELECTROCHEMICAL

SCIENCE

WwW.electrochemsci.org

\title{
Influence of Surfactants on Electrochemical Chloride Extraction in Reinforced Cement Mortar
}

\author{
Yang Wang, Jinxia Xu*, Wei Feng, Linhua Jiang \\ College of Mechanics and Materials, Hohai University, Nanjing 210098, PR China \\ *E-mail: xujinxia@hhu.edu.cn
}

doi: $10.20964 / 2020.03 .27$

Received: 2 November 2019 / Accepted: 28 December 2019 / Published: 10 February 2020

This paper aims to examine the effect of surfactants on the electrochemical chloride extraction for remediating the chloride contaminated reinforced cement mortar. Triethanolamine dodecyl sulfate (TADS) and sodium dodecyl benzene sulfonate (SDBS) were chosen to represent as cationic surfactant and anionic surfactant, respectively. Different applied potentials of $20 \mathrm{~V}, 40 \mathrm{~V}$ and $60 \mathrm{~V}$ were applied. The extracted chlorides in electrolytes, residual chlorides in mortar, energy consumption, corrosion potential and corrosion current density (decided by half-cell potential and potentiodynamic polarization) of embedded steel were measured. The results indicate that the surfactants increase obviously the efficiency of electrochemical chloride extraction. Compared to SDBS, TADS has a better effect of chloride removal. Besides, the surfactants reduce the energy consumption. Furthermore, the decreases of the $I_{\text {corr }}$ values and increases of the $E_{\text {corr }}$ values for the embedded steels due to the additions of surfactants are obtained after the electrochemical treatments. Accordingly, the surfactants can be applied to improve the remediation effect of electrochemical chloride extraction on the chloride-contaminated concrete structures in real environment.

Keywords: Electrochemical chloride extraction; chloride extraction efficiency; surfactants; corrosion potential; corrosion current density.

\section{$\underline{\text { FULL TEXT }}$}

(C) 2020 The Authors. Published by ESG (www.electrochemsci.org). This article is an open access article distributed under the terms and conditions of the Creative Commons Attribution license (http://creativecommons.org/licenses/by/4.0/). 